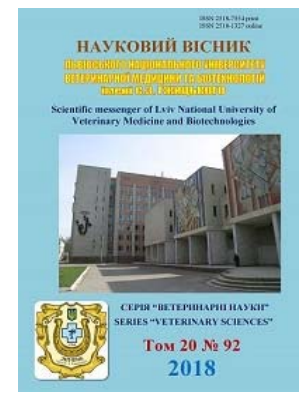

\author{
Науковий вісник Дьвівського національного університету \\ ветеринарної медицини та біотехнологій імені С.3. Гжицького
}

\author{
Scientific Messenger of Lviv National University \\ of Veterinary Medicine and Biotechnologies
}

\title{
Evaluation of the cleansing and disinfection protocol of pig-breeding premises contaminated by the porcine epidemic diarrhea virus
}

\author{
D.M. Masiuk, O.I. Sosnztskyi, A.V. Kokariev, T.O. Vasilenko \\ Dnipro State Agrarian and Economic University, Dnipro, Ukraine
}

\section{Article info}

Received 23.10.2018

Received in revised form 23.11 .2018

Accepted 26.11.2018

Dnipro State Agrarian and Economic University,

25 Serhiya Yefremova Street

Dnipro, 49000, Ukraine.

Tel.: +38-050-636-62-37

E-mail:plppm@ua.fn
Masiuk, D.M., Sosnztskyi, O.I., Kokariev, A.V., \& Vasilenko, T.O. (2018). Evaluation of the cleansing and disinfection protocol of pig-breeding premises contaminated by the porcine epidemic diarrhea virus. Scientific Messenger of Lviv National University of Veterinary Medicine and Biotechnologies, 20(92), 130-136. doi: 10.32718/nvlvet9227

The results of the determination of the efficiency of the cleaning and disinfection protocol of pig farms contaminated by the porcine epidemic diarrhea virus are presented in this study. The research was conducted in the Scientific Research Center of Biosafety and Environmental Control AIC of the Dnipro State Agrarian and Economic University. The experimental part was carried out on the basis of a permanently infected pig breeding farm of the southern region of Ukraine. In order to determine the critical points, a selection of samples of washings/scraps from the surfaces of the pig farm's premises and the objects of the environment was carried out before cleaning and disinfection and after 1 and 2 premises' sanitation. A total of 204 tests were analyzed. Disinfection of the territory of pig farms and livestock premises was carried out in accordance with generally accepted methods. Before disinfection, a thorough mechanical cleaning of livestock premises was carried out, with subsequent irrigation of all surfaces with cold tap water. Disinfection of premises and the territory of the pig complex was carried out by the wet cleaning of surfaces with a solution of disinfectant based on glutaraldehyde after preparatory operations in the absence of animals. After disinfection the premises were additionally processed with $\mathrm{Ca}(\mathrm{OH})_{2}$ solution. Washes were obtained with a sterile swab from a surface of $10.0 \mathrm{~cm}^{2}$ by inserting a swab into a test tube with a sterile physiological solution. Scraps from the surfaces were obtained with a disposable sterile blades from the scalpel. The obtained material was placed in disposable sterile plastic $1.5-2.0 \mathrm{~cm}^{3}$ test tubes. The study of the presence of the PEDV was performed using a real-time polymerase chain reaction with the previous reverse transcription of RNA. It was established that the causative agent of PED in a permanently infected farm contaminates most of the production and auxiliary premises and objects of the environment. The one-time cleaning and disinfection protocol does not allow free the farm from the PEDV completely. Only two-time sanitation of premises and objects of the environment with the laboratory control of the efficiency of cleaning and disinfection contributes to the effective eradication of the PEDV.

Key words: sanation, PED, PEDv, RT-PCR, washings, contamination.

\section{Оцінка протоколу очищення та дезінфекції у свинарських приміщеннях контамінованих вірусом епідемічної діареї свиней}

\author{
Д.М. Масюк, О.І. Сосницький, А.В. Кокарєв, Т.О. Василенко \\ Дніпровський державний аграрно-економічний університет, м. Дніпро, Україна
}

У роботі представлено результати визначення ефективності протоколу очищення та дезінфекції у свинарських приміщеннях контамінованих вірусом епідемічної діареї свиней. Дослідження проведені в Науково-дослідному иентрі біобезпеки та екологічного контролю ресурсів агропромислового комплексу Дніпровського державного аграрно-економічного університету. Експериментальна частина проведена на базі стачіонарно неблагополучного свинарського підприємства південного регіону України. Для визначення критичних точок було проведено відбір зразків змивів / зішкрібів з поверхонь приміщень свиноферми та об'єктів навколишнього середовища до проведення очищення та дезінфекиї та після 1 i 2 саначії приміщень. Всього було протестована 204 проб. Дезінфекцію території свинарських комплексів і твариннищьких приміщень проводили згідно загальноприйнятих способів. Перед дезінфекцією проводили ретельне механічне очищення тваринницьких приміщень з подальшим зрошенням всіх поверхонь холодної водопро- 
відної водою. Після підготовчих операцій проводили дезінфекиію свинарських приміщень і території свинокомплексу, за відсутності тварин, вологою обробкою поверхні розчином дезінфікуючого засобу на основі глутарового альдегіду. Після дезінфекиії приміщення додатково проводили обробку свіжо гашеним вапном. Змиви проводили стерильним тампоном з поверхні розміром 10,0 см ${ }^{2}$, встромлюючи тампон в пробірку із стерильним фізіологічним розчином. Зішкріби з поверхонь проводили одноразовими стерильними лезами від скальпеля. Отриманий матеріал помімали в одноразові стерильні пластикові пробірки об'ємом 1,5-2,0 см'. Дослідження наявності вірусу ЕДС проводили за допомогою полімеразної ланиюгової реакиї із детекиією результатів у реальному часі за попередньої зворотної транскрипиії РНК (RT-PCR). Встановлено, щзо збудник ЕДС у стаціонарно неблагополучному господарстві контамінує більшість виробничих і допоміжних приміщень та об'єктів навколишнього середовища. Використаний одноразовий протокол очищення та дезінфекиії не дає змогу повністю звільнити господарство від вірусу ЕДС. Лише дворазова санація приміщень та об'єктів навколишнього середовища, яка відбувається з урахуванням результатів лабораторного контролю ефективності очищення та дезінфекиії сприяє ефективній ерадикаџї збуднику ЕДС.

Ключові слова: саначія, ЕДС, РEDv, RT-PCR, змиви, зішкріби, контамінація.

\section{Вступ}

Дезінфекція тваринницьких приміщень, забруднених вірусом епідемічної діареї свиней $(P E D v)$, є обов'язковим елементом протиепізоотичних заходів, спрямованих на санування та ерадикацію збудника епідемічної діареї свиней (ЕДС) з довкілля сприйнятливих тварин. Тільки повне знезараження тваринницької ферми в поєднанні з елімінацією збудника 3 організму свиней дає можливість звільниться від циркуляції збудника ЕДС серед сприйнятливих тварин (Dee et al., 2018; Gosling, 2018). Необхідно враховувати, що новонароджені неімунні поросята $є$ надчуттєвими і облігатно сприйнятливими макроорганізмами до $P E D v$, саме тому вони є біоіндикатором збудника ЕДС, який зберігається у навколишньому середовищі на різноманітному технологічному обладнанні в різних тваринницьких приміщеннях (Trudeau et al., 2017).

$P E D v$ відноситься до РНК-коронавірусу, який має ліпопротеїнову оболонку, що обумовлює іх ефіро - i хлороформчутливість. Пеплос i пепломіри вірусу руйнуються дезоксихолатом натрію, детергентами i загальноприйнятими концентраціями поширених дезінфікуючих засобів. Вірус інактивується 0,03\% розчином формаліну, $0,01 \%$ розчином $\beta$ пропіолактону, $1 \%$ розчином Lysovet (суміш фенолу та альдегіду), слабкими розчинами їдкого натрію, гіпохлориду натрію, йоду, тощо (Bowman et al., 2015; Gosling, 2018). PEDv стійкий до трипсину, жовчі, $\mathrm{pH}$ $3,0-9,0$, низьких температур, триразове заморожування-відтавання не знижує інфекційність збудника. У рідких фекаліях на сонці вірус втрачає інфекційність протягом 6 год, в тіні - за 3 доби. Високі температури і прямі сонячні промені діють згубно (Jung and Chae, 2004; Thomas et al., 2014; Cochrane et al., 2017).

В Україні зареєстровані і застосовуються різноманітні офіційні дезінфікуючі препарати проти інфекційних агентів різної природи. Проти вірусних і бактеріальних інфекцій ефективні Аеродез, Біодез, Біодез-Екстра ДВУ, Біо-Лонг, Віросан, Віркон С, Гексахлорфен, ДЗПТ-2, Дезконтен, Дезолайн-Д, Діновіс, Жавель-Клейд, Міксамін, Новодез, Полідез, Септадор, Септокс, Тріосепт-Екстра, Теотропін-П, ТріосептЕндо, Хлорамін Б, Ектерецід, Епідез, Епідез М, Екоцид C, група Desu, Incimaxxc T, Environ та ін.

Вдало застосовують розчини формаліну з вмістом 1,5\% формальдегіду, розчин нейтрального гіпохлориду кальцію з вмістом 5,0\% активного хлору, 5,0\% розчин хлораміну, хлорне вапно, з вмістом не менш як $25,0 \%$ активного хлору, перекис водню, однохлористого йоду, йодозоль, йодис, $3,0 \%$ гарячий розчин їдкого натру та ін. (Gerber et al., 2014; Bowman et al., 2015; Quist-rybachuk et al., 2015; Tun et al., 2016; Baker et al., 2017; Holtkamp et al., 2017; Martelli et al., 2017; Trudeau et al., 2017).

При дотриманні нормативних вимог до умов проведення процесу дезінфекції та концентрації активно діючої речовини в лабораторних умовах отримують ефективні результати стосовно інактивації інфекційного агента (Ojeh et al., 1995), але в реальних умовах тваринницького комплексу завжди знаходяться важкодоступні місця, до яких не проникає дезінфектант у необхідних концентраціях, у результаті чого не витримується технологічна експозиція, що знижує віруліцидну дію препарату і зберігає біологічно активний вірус - потенційне джерело реінфекції ЕДС (Waddilove and Blackwell, 1997; Thomson et al., 2007; Luyckx et al., 2016).

Мета роботи: визначити ефективність протоколу очищення та дезінфекції у свинарських приміщеннях контамінованих вірусом епідемічної діареї свиней.

\section{Матеріал і методи досліджень}

Дослідження проведені в Науково-дослідному центрі біобезпеки та екологічного контролю ресурсів агропромислового комплексу Дніпровського державного аграрно-економічного університету відповідно до Наукової теми "Визначення теоретичних аспектів епізоотичного процесу 3 урахуванням генетичних варіантів штамів вірусу епідемічної діареї свиней" (№ державної реєстрації 0117U004293). Експериментальна частина проведена на базі стаціонарно неблагополучного свинарського підприємства південного регіону України.

Для визначення критичних точок було проведено відбір зразків змивів / зішкрібів з поверхонь приміщень свиноферми та об'єктів навколишнього середовища до проведення очищення та дезінфекції та після 1 і 2 санації приміщень. Всього було протестована 204 проб.

Дезінфекцію території свинарських комплексів і тваринницьких приміщень проводили згідно загальноприйнятих способів проведення даного заходу за вірусних інфекцій, викликаних оболонковими вірусами, які мають невисоку стійкість до інгібуючих фізико-хімічних впливів зовнішнього середовища, особливо хімікатів, які володіють детергентними власти- 
востями і руйнують ліпідну оболонку вірусу або є активними окислювачами.

Перед заключною дезінфекцією проводили ретельне механічне очищення тваринницьких приміщень 3 подальшим зрошенням всіх поверхонь холодною водопровідною водою. Після підготовчих операцій проводили заключну дезінфекцію свинарських приміщень, за відсутності тварин, і території свинокомплексу вологою обробкою поверхні розчином дезінфікуючого засобу “Віросан”. Це дезінфектант на основі глутарового альдегіду. Препарат використовували згідно з інструкцією до використання з експозицією протягом години.

Після дезінфекції приміщення додатково проводили обробку свіжогашеним вапном, а перед введенням тварин до свинарнику, всі поверхні й технологічне обладнання посипали препаратом “Айліксін” (аналог “хлораміну”).

Змиви проводили стерильним тампоном з поверхні розміром 10,0 см², встромлюючи тампон в пробірку із стерильним фізіологічним розчином. Зішкріби з поверхонь проводили одноразовими стерильними лезами від скальпеля. Отриманий матеріал поміщали в одноразові стерильні пластикові пробірки об'ємом 1,5$2,0 \mathrm{~cm}^{3}$.

Дослідження наявності вірусу ЕДС проводили за допомогою полімеразної ланцюгової реакції із детекцією результатів у реальному часі за попередньої зворотної транскрипції РНК (RT-PCR).

Екстракцію тотального генетичного матеріалу iз зразків здійснювали за допомогою комерційного набору для виділення ДНК / РНК “BioExtract®Column Kit" ("Biosellal”, Франція).

Зворотну транскрипцію РНК вірусу ЕДС і реплікацію кДНК проводили за допомогою набору реактивів "Bio-T kit@PEDV all - TGEV" ("Biosellal", Франція) на ампліфікаторі CFX 96 Real-Time System ("Bio Rad”, США) згідно температурного режиму (табл. 1).

\section{Таблиця 1}

Температурний режим ампліфікації

\begin{tabular}{cccc}
\hline $\begin{array}{c}\text { № } \\
\text { этапу }\end{array}$ & Температура, ${ }^{\circ} \mathrm{C}$ & $\begin{array}{c}\text { Час, } \\
\text { секунд }\end{array}$ & $\begin{array}{c}\text { Кількість } \\
\text { циклів, шт }\end{array}$ \\
\hline 1 & 50 & 1200 & 1 \\
2 & 95 & 300 & 1 \\
3 & 95 & 10 & 45 \\
4 & 60 & 45 & \\
\hline
\end{tabular}

Вимірювання рівня флуоресценції зразків здійснювали в режимі реального часу на 4-му етапі температурного режиму.

Облік результатів ампліфікації, а також визначення значення порогового циклу реакції (threshold cycle, $\mathrm{Ct})$ проводили за допомогою програмного забезпечення "Bio-Rad CFX Manager".

\section{Результати та їх обговорення}

В одному 3 свинарських господарств 3 інтенсивною технологією ведення тваринництва в південному регіоні України, неблагополучному по ЕДС, проведено молекулярно-генетичне дослідження, спрямоване на визначення якості та ефективності стандартних дезінфекційних заходів, які використовують при санації господарства від $P E D v$.

Опрацьовуючи експериментальні дані, викладені в таблицях 2-6, встановили, що після першої і другої дезінфекції на свинокомплексі методом молекулярногенетичного аналізу виявлена цільова послідовність кДНК $P E D v$ на різних предметах технологічного обладнання та ділянках приміщень, які розташовані мозаїчно та не упорядковано - контаміновані і знезаражені ділянки зустрічаються повсюди і стикаються між собою.

\section{Таблиця 2}

Результати скринінгу кДНК $P E D v$ на знезаражуваних поверхнях галереї та сектора кнурів, $\mathrm{Ct}$

\begin{tabular}{|c|c|c|c|}
\hline Досліджуваний об'єкт & До дезінфекції & Після 1 дезінфекції & Після 2 дезінфекції \\
\hline \multicolumn{4}{|c|}{ Галерея } \\
\hline Вхід & NA & NA & NA \\
\hline Підлога & 37,62 & NA & NA \\
\hline Транспортер & 35,94 & 39,57 & NA \\
\hline Коридор & 39,21 & NA & NA \\
\hline Мийка & 39,27 & NA & NA \\
\hline Коридор & 34,38 & NA & NA \\
\hline \multicolumn{4}{|c|}{ Сектор кнурів } \\
\hline Санітарний пропускник & NA & NA & NA \\
\hline Підлога в клітках & 39,40 & NA & NA \\
\hline Підлога в проході & 38,31 & NA & NA \\
\hline Підлога під годівницею & NA & NA & NA \\
\hline Зливна яма & 39,19 & NA & NA \\
\hline Піранії & NA & NA & NA \\
\hline
\end{tabular}

Примітка: NA - не виявлено

При досліджені змивів та зішкрібів з поверхонь об'єктів галереї та сектору кнурів встановлено, що до проведення дезінфекції галереї у 5 з 6 проб виявлено генетичний матеріал $P E D v$, а в секторі кнурів - у 33
6 проб. Після першої дезінфекції виявлено слідові кількості РНК вірусу лише в змивах з транспортеру у галереї, що вказує на низьку ефективність проведених дезінфекційних заходів. Жодна проба змивів, відібра- 
них із сектору кнурів, не містила генетичного матеріалу $P E D v$. Після останньої дезінфекції всі досліджувані проби були негативними.

Дослідження змивів та зішкрібів 3 поверхонь об'єктів свинарників сектору дорощування (табл. 3) вказують на широку розповсюдженість вірусів у приміщеннях сектору дорощування. Це підтверджується наявністю генетичного матеріалу вірусу ЕДС у 43 6 досліджуваних проб.

Після першої санації приміщення більшість поверхонь зовнішніх об'єктів були позбавлені вірусу ЕДС, але все рівно генетичний матеріал збуднику виявлено в змивах 3 підлоги під годівницею, зливній ямі та підлозі в клітках, що вказує на нестопроцентну дезінфекцію під час першої санації приміщень.

Слід зазначити, що збудник ЕДС є висококонтагіозним вірусом, а тому навіть незначна його кількість, яку виявлено після другої санації приміщень, за умов надходження до сприйнятливого організму, який не має специфічного імунного захисту, може індукувати розвиток діарейного синдрому, що особливо актуально для неонатальних поросят (Masiuk et al., 2017).

\section{Таблиця 3}

Результати скринінгу кДНК $P E D v$ на знезаражуваних поверхнях сектору дорощування, $\mathrm{Ct}$

\begin{tabular}{|c|c|c|c|}
\hline Досліджуваний об’єкт & До дезінфекції & Після 1 дезінфекції & Після 2 дезінфекції \\
\hline \multicolumn{4}{|c|}{ Сектор дорощування: свинарник №1 } \\
\hline Санітарний пропускник & 39,76 & NA & NA \\
\hline Підлога в клітках & NA & NA & NA \\
\hline Підлога в проході & 38,79 & NA & NA \\
\hline Підлога під годівницею & NA & 39,15 & NA \\
\hline Зливна яма & 39,41 & NA & NA \\
\hline Піранії & 32,91 & NA & NA \\
\hline \multicolumn{4}{|c|}{ Сектор дорощування: свинарник №2 } \\
\hline Санітарний пропускник & 38,44 & NA & NA \\
\hline Підлога в клітках & 35,30 & 38,48 & NA \\
\hline Підлога в проході & 31,76 & NA & NA \\
\hline Підлога під годівницею & NA & NA & NA \\
\hline Зливна яма & 32,70 & 39,16 & NA \\
\hline Піранії & 37,81 & NA & NA \\
\hline
\end{tabular}

Примітка: NA - не виявлено

Друга дезінфекція свинарників із сектору дорощування вказує на відсутність збуднику у 100\% досліджуваних зразках із поверхонь об’єктів зовнішнього середовища. Це свідчить про ефективно проведені дезінфекційні заходи, які направлені на звільнення приміщень від вірусу ЕДС з урахуванням критичних місць зберігання збуднику коронавірусної інфекції в зовнішньому середовищі.

\section{Таблиця 4}

Результати скринінгу кДНК $P E D v$ на знезаражуваних поверхнях сектору відгодівлі, $\mathrm{Ct}$

\begin{tabular}{|c|c|c|c|}
\hline Досліджуваний об’єкт & До дезінфекції & Після 1 дезінфекції & Після 2 дезінфекції \\
\hline \multicolumn{4}{|c|}{ Сектор відгодівлі: свинарник №1 } \\
\hline Санітарний пропускник & NA & NA & NA \\
\hline Підлога в клітках & 32,22 & NA & NA \\
\hline Підлога в проході & NA & NA & NA \\
\hline Підлога під годівницею & 39,29 & NA & NA \\
\hline Зливна яма & 38,40 & NA & NA \\
\hline Піранії & 34,23 & NA & NA \\
\hline \multicolumn{4}{|c|}{ Сектор відгодівлі: свинарник №2 } \\
\hline Санітарний пропускник & 39,35 & NA & NA \\
\hline Підлога в клітках & NA & NA & NA \\
\hline Підлога в проході & 37,57 & NA & NA \\
\hline Підлога під годівницею & 31,14 & NA & NA \\
\hline Зливна яма & 35,19 & NA & NA \\
\hline Піранії & NA & NA & NA \\
\hline \multicolumn{4}{|c|}{ Сектор відгодівлі: свинарник №3 } \\
\hline Санітарний пропускник & NA & NA & NA \\
\hline Підлога в клітках & 39,10 & NA & NA \\
\hline Підлога в проході & NA & NA & NA \\
\hline Підлога під годівницею & NA & NA & NA \\
\hline Зливна яма & 34,68 & NA & NA \\
\hline Піранії & 37,88 & NA & NA \\
\hline
\end{tabular}


Дослідження змивів з поверхонь об'єктів із сектору відгодівлі вказують на значне розповсюдження вірусу серед цих свинарників. Так, у першому приміщенні вірус виявлено у 4 з 6 проб. При цьому найбільша кількість містилась у змивах з підлоги кліток та піраній. У другому приміщенні присутність вірусу була виявлена у змивах із зливної ями, біля санітарного пропускника та на підлозі свинарника. Схожі результати були отримані при досліджені третього свинарника.
Вже після першої та після другої санацій приміщень, всі проби змивів були вільними від генетичного матеріалу вірусу ЕДС. Це вказує на високу ефективність використаного протоколу очищення та дезінфекції свинарських приміщень.

Найбільша кількість вірусу було виявлено в змивах з поверхонь об'єктів та приміщень у свинарнику в приміщеннях сектору маточника: свинарника № 1 і 2 (табл. 5).

\section{Таблиця 5}

Результати скринінгу кДНК $P E D v$ на знезаражуваних поверхнях секторів маточника та ремонтного молодняку, $\mathrm{Ct}$

\begin{tabular}{|c|c|c|c|}
\hline Досліджуваний об’єкт & До дезінфекції & Після 1 дезінфекції & Після 2 дезінфекції \\
\hline \multicolumn{4}{|c|}{ Сектор маточника: свинарник № 1} \\
\hline Санітарний пропускник & 33,94 & NA & NA \\
\hline Підлога в клітках & 34,42 & 39,22 & NA \\
\hline Підлога в проході & NA & NA & NA \\
\hline Підлога під годівницею & 39,20 & NA & NA \\
\hline Зливна яма & 35,81 & 40,13 & NA \\
\hline Піранії & 38,28 & NA & NA \\
\hline \multicolumn{4}{|c|}{ Сектор маточника: свинарник № 2} \\
\hline Санітарний пропускник & 39,78 & NA & NA \\
\hline Підлога в клітках & 31,35 & 38,79 & NA \\
\hline Підлога в проході & NA & 39,41 & NA \\
\hline Підлога під годівницею & 38,20 & NA & NA \\
\hline Зливна яма & 32,64 & 41,85 & NA \\
\hline Піранії & 39,50 & NA & NA \\
\hline \multicolumn{4}{|c|}{ Сектор ремонтного молодняку } \\
\hline Санітарний пропускник & NA & NA & NA \\
\hline Підлога в клітках & NA & NA & NA \\
\hline Підлога в проході & NA & NA & NA \\
\hline Підлога під годівницею & NA & NA & NA \\
\hline Зливна яма & 34,60 & NA & NA \\
\hline Піранії & NA & NA & NA \\
\hline
\end{tabular}

Примітка: NA - не виявлено

Після першої санації приміщень вірус було виявлено у 5 з 6 контрольних точок обох приміщень. У приміщенні, де утримувався ремонтний молодняк, лише одна проба змиву із зливної ями містила РНК вірусу ЕДС.

3 урахуванням отриманих результатів, які вказують на місця зберігання вірусу ЕДС у зовнішньому середовищі, було проведено очищення та дезінфекцію приміщень, у результаті чого сектор ремонтного молодняку повністю звільнений від збуднику ЕДС. На це вказують отримані негативні результати RT-PCR після першої та другої санації. У той же час на поверхнях у приміщеннях маточників виявлено кДНК вірусу ЕДС після проведення першого очищення та дезінфекції. При цьому в першому свинарнику виявлено 2 з 6 проб, а у другому свинарнику - 3 з 6 проб змивів 3 поверхонь, що були контаміновані генетичним матеріалом вірусу ЕДС. Слід відзначити, що досліджувані проби після другої санації приміщень містять на 2-3 логарифми меншу кількість збуднику ЕДС, порівняно до результатів, отриманих після першого очищення та дезінфекції. На це вказує збільшення у позитивно реагуючих пробах показнику Ct на 6 одиниць i більше (Ojeh et al., 1995).
Друге очищення та дезінфекція тваринницьких приміщень сприяли звільненню навколишнього середовища корпусів маточнику від вірусу ЕДС, що підтверджується негативним результатом тестування змивів поверхонь об'єктів свинарників методом RTPCR.

Скринінг генетичного матеріалу вірусу ЕДС з поверхонь інших об'єктів, що знаходяться на території свинокомплексу вказують на значне розповсюдження вірусу у зовнішньому середовищі (табл. 6).

Генетичний матеріал вірусу ЕДС було виявлено в пробах змивів відібраних з поверхонь біля центрального санітарного пропускнику свинокомплексу та чоловічого санітарного пропускнику, а також у кабінеті ветеринарного лікаря, ветеринарній аптеці та скотовозі. Останній досить часто є джерелом розповсюдження коронавірусної інфекції (Thomas et al., 2014).

Після проведення першого очищення та дезінфекції сліди генетичного матеріалу вірусу ЕДС виявлено у кабінеті ветеринарного лікаря та скотовозі. Після другої санації вище зазначених об'єктів результати дослідження змивів 3 їх поверхонь мали негативний результат, що вказує на відсутність вірусу в досліджуваних зразках. 


\section{Таблиця 6}

Результати скринінгу кДНК $P E D v$ на знезаражуваних поверхнях інших об'єктів, що знаходяться на території свинокомплексу, $\mathrm{Ct}$

\begin{tabular}{lccc}
\hline \multicolumn{1}{c}{ Досліджуваний об’єкт } & До дезінфекції & Після 1 дезінфекції & Після 2 дезінфекції \\
\hline Санітарний пропускник (центральний) & 32,39 & NA & NA \\
Жіночий санпропускник & NA & NA & NA \\
Чоловічий санпропускник & 31,60 & NA & NA \\
Кабінет ветеринарного лікаря & 32,46 & 40,90 & NA \\
Ветеринарна аптека & 33,34 & NA & NA \\
Виїзд з ферми & NA & NA & NA \\
Скотовоз & 33,13 & 39,52 & NA \\
Холодильник & NA & NA & NA \\
\hline
\end{tabular}

Примітка: NA - не виявлено

Отже, у стаціонарно неблагополучному господарстві за ЕДС вірус $є$ широко розповсюдженим у навколишньому середовищі.

Дослідження якості протоколу очищення та дезінфекції вказують на низьку ефективність одноразової санації приміщень та прилеглої території, тоді як дворазова обробка поверхонь об'єктів зовнішнього середовища сприяє більш ефективному видаленню вірусу ЕДС з території господарства.

\section{Висновки}

Збудник ЕДС у стаціонарно неблагополучному господарстві контамінує більшість виробничих і допоміжних приміщень та об'єктів навколишнього середовища. Використаний одноразовий протокол очищення та дезінфекції не дає змогу повністю звільнити господарство від вірусу ЕДС. Лише дворазова санація приміщень та об'єктів навколишнього середовища, яка відбувається з урахуванням результатів лабораторного контролю ефективності очищення та дезінфекції сприяє ефективній ерадикації збуднику ЕДС.

\section{References}

Baker, K.L., Thomas, P.R., Karriker, L.A., Ramirez, A., Zhang, J., Wang, C., \& Holtkamp, D.J. (2017). Evaluation of an accelerated hydrogen peroxide disinfectant to inactivate porcine epidemic diarrhea virus in swine feces on aluminum surfaces under freezing conditions. BMC veterinary research, 13(1), 372. doi: 10.1186/s12917-017-1300-4.

Bowman, A.S., Nolting, J.M., Nelson, S.W., Bliss, N., Stull, J.W., Wang, Q., \& Premanandan, C. (2015). Effects of disinfection on the molecular detection of porcine epidemic diarrhea virus. Veterinary Microbiology, 179(3-4), 213-218. doi: 10.1016/j.vetmic.2015.05.027.

Cochrane, R.A., Schumacher, L.L., Dritz, S.S., Woodworth, J.C., Huss, A.R., Stark, C.R., DeRouchey, J.M., Tokach, M.D., Goodband, R.D., Bia, J., Chen, Q., Zhang, J., Gauger, P.C., Derscheid, R.J., Magstadt, D.R., Main, R.G., \& Jones, C.K. (2017). Effect of pelleting on survival of porcine epidemic diarrhea viruscontaminated feed. Journal of Animal Science, 95(3), 1170-1178. doi: 10.2527/jas.2016.0961.

Corona-Barrera, E., Smith, D.G.E., Murray, B., \& Thomson, J.R. (2004). Efficacy of seven disinfectant sanitisers on field isolates of Brachyspira pilosicoli. Veterinary Record, 154, 473-474. doi: 10.1136/vr.154.15.473.

Dee, S.A., Bauermann, F.V., Niederwerder, M.C., Singrey, A., Clement, T., Lima de M., Long, C., Patterson, G., Sheahan, M.A., \& Stoin, A.M. (2018). Survival of viral pathogens in animal feed ingredients under transboundary shipping models. PLoS One, 13:0194509. doi: 10.1371/jornal.pone.0194509.

Gerber, P.F., Xiao, C.-T., Chen, Q., Zhang, J., Halbur, P. G., \& Opriessnig, T. (2014). The spraydrying process is sufficient to inactivate infectious porcine epidemic diarrhea virus in plasma. Veterinary Microbiology, 174, 86-92. doi: 10,1016/j.vetmic.2014.09.008.

Gosling, R.J. (2018). A review of cleaning and disinfection studies in farming environments. Livestock Science, 23(5), 232. doi: 10.12968/live.2018.23.5.232.

Holtkamp, D.J., Myers, J., Thomas, P.R., Karriker, L.A., Ramirez, A., Zhang, J., \& Wang, C. (2017). Efficacy of an accelerated hydrogen peroxide disinfectant to inactivate porcine epidemic diarrhea virus in swine feces on metal surfaces. Canadian journal of veterinary research, 81(2), 100-107. https:/www.ncbi.nlm.nih. gov/pubmed/28408777.

Jung, K., \& Chae, C. (2004). Effect of temperature on the detection of porcine epidemic diarrhea virus and transmissible gastroenteritis virus in fecal samples by reverse transcriptionpolymerase chain reaction. Journal of Veterinary Diagnostic Investigation, 16(3), 237-239. doi: 10.1177/104063870401600312.

Luyckx, K., Millet, S., Weyenberg, V., Herman, L., Heyndrickx, M., Dewulf, J., \& De Reu, K. (2016). Comparison of competitive exclusion with classical cleaning and disinfection on bacterial load in pig nursery units. Veterinary Research BMC, 12, 189. doi: 10.1186/s12917-016-0810-9.

Masiuk, D.M., Sosnitsky, O.I., Nedzvetsky, V.S., Kokarev, A.V., \& Koliada, S.G. (2017). Endemic course of epidemic diarrhea of pigs in the stabilized focus of infection. Regulatory Mechanisms in Biosystems, 8(3), 410-416. doi: 10.15421/021763.

Martelli, F., Lambert, M., Butt, P., Cheney, T., Tatone, F. A., Callaby, R., Rabie, A., Gosling, R. J., Fordon, S., Crocker, G., Davies, R.H., \& Smith, R.P. (2017). Evaluation of an enhanced cleaning and disinfection protocol in Salmonella contaminated pig holdings in the United Kingdom. PloS one, 12(6), e0178897. doi: 10.1371/journal.pone.0178897. 
Ojeh, C.K., Cusack, T.M., \& Yolken, R.H. (1995). Evaluation of the effects of disinfectants on rotavirus RNA and infectivity by the polymerase chain reaction and cell-culture methods. Molecular and Cellular Probes, 9(5), 341-346. doi: 10.1016/S0890-8508(95)91652-0.

Thomas, P., Karriker, A.L., Ramirez, A., Zhang, J., Ellingson, J.S., \& Holtkamp, D.J. (2014). Methods for inactivating PEDV in Hog Trailers. Twenty-second Annual Swine Disease Conference for Swine Practitioners, 13-14, 43-50. doi: 10.31274/ans air-1808141366.

Thomson, J.R., Bell, N.A., \& Rafferty, M. (2007). Efficacy of some disinfectant compounds against porcine bacterial pathogens. Pig Journal, 60.

Trudeau, M.P., Verma, H., Sampedro, F., Urriola, P.E., Shurson, G.C., \& Goyal, S.M. (2017). Environmental persistence of porcine coronaviruses in feed and feed ingredients. PloS one, 12(5), e0178094. doi: 10.1371/journal.pone.0178094.

Trudeau, M.P., Verma, H., Urriola, P.E., Sampedro, F., Shurson, G.C., Goyal, S.M. (2017). Survival of porcine epidemic diarrhea virus (PEDV) in thermally treated feed ingredients and on surfaces. Porcine Health Management, 19(3), 17. doi: 10.1186/s40813017-0064-3.

Tun, H.M., Cai, Z., \& Khafipour, E. (2016). Monitoring Survivability and Infectivity of Porcine Epidemic Diarrhea Virus (PEDv) in the Infected On-Farm Earthen Manure Storages (EMS). Frontiers in Microbiology, 7, 265. doi: 10.3389/fmicb.2016.00265.

Quist-rybachuk, G.V., Nauwynck, H.J., \& Kalmar, I.D. (2015). Sensitivity of porcine epidemic diarrhea virus (PEDV) to $\mathrm{pH}$ and heat treatment in the presence or absence of porcine plasma. Veterinary Microbiology, 181(3-4), 283-288. doi: 10.1016/j.vetmic.2015.10.010.

Waddilove, J., \& Blackwell, M. (1997). Disinfection of pig units. Pig Journal, 40, 28-37.

Mandigra, M.S., Lisicja, A.V., Zhigaljuk, S.V., Dmitriyev, I.M., Velichko, Ju.M., Andrushhuk I.L., Mandigra, Ju.M., \& Romanishina, O.O. (2012). Analiz zasobiv dlja veterinarnoi dezynfekcii. Veterynarna medycyna, 96, 163-165. http://jvm.kharkov.ua/sbornik/96/65.pdf (in Ukrainian). 